\title{
Analyses of THOR Treatment Technologies CP-2 Corrosion Coupons (U)
}

\author{
K. H. Subramanian \\ Savannah River National Laboratory \\ Strategic Materials Technology Department \\ Materials Technology Section
}

Publication Date: July 2006

Westinghouse Savannah River Company

Savannah River Site

Aiken, SC 29808

This document was prepared in connection with work done under Contract No. DE-AC09-96SR18500 with the U. S. Department of Energy 
WSRC-TR-2006-00268

\section{DISCLAIMER}

This report was prepared as an account of work sponsored by an agency of the United States Government. Neither the United States Government nor any agency thereof, nor any of their employees, makes any warranty, express or implied, or assumes any legal liability or responsibility for the accuracy, completeness, or usefulness of any information, apparatus, product, or process disclosed, or represents that its use would not infringe privately owned rights. Reference herein to any specific commercial product, process, or service by trade name, trademark, manufacturer, or otherwise does not necessarily constitute or imply its endorsement, recommendation, or favoring by the United States Government or any agency thereof. The views and opinions of authors expressed herein do not necessarily state or reflect those of the United States Government or any agency thereof. 
DOCUMENT:

TITLE:

\section{APPROVALS}

K. H. Subramanian, Author

WSRC-TR-2006-00268

Analyses of THOR Treatment Technologies CP-2 Corrosion Coupons (U)

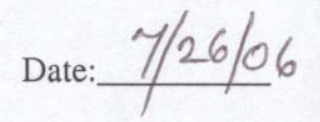

Materials Performance and Corrosion Technology

Materials Science and Technology Directorate
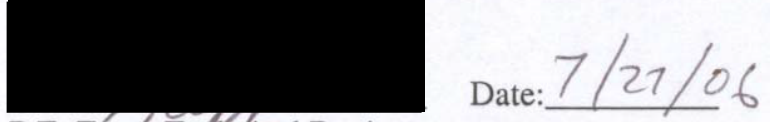

P.E. Zapp, Technical Reviewer

Materials Performance and Corrosion Technology

Materials Science and Technology Directorate
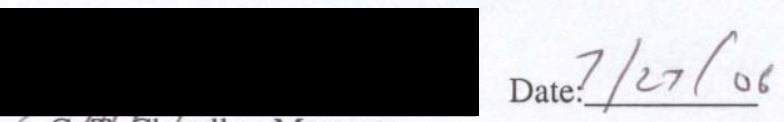

G. P. Chándler, Manager

Materials Performance and Corrosion Technology

Materials Science and Technology Directorate

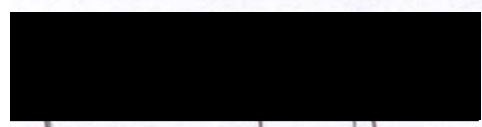

Date: $7 / 27 / 06$

\footnotetext{
N. C. Iyer, Director

Materials Science and Technology Directorate

Savannah River National Laboratory
} 


\section{$\underline{\text { Table of Contents }}$}

1 SUMMARY

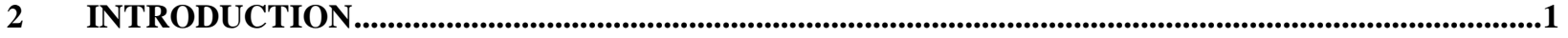

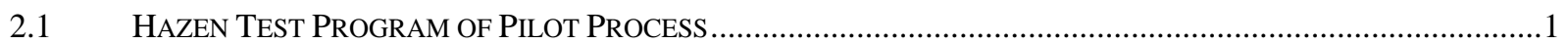

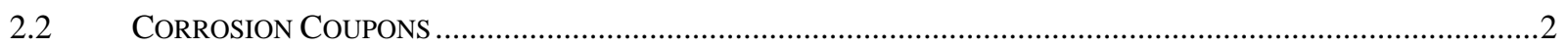

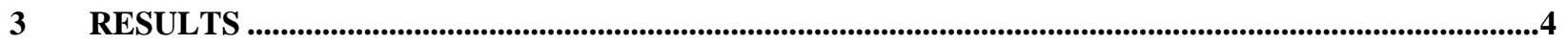

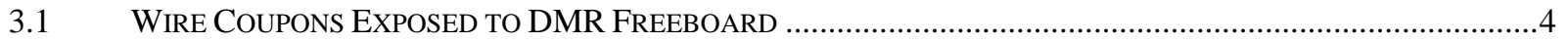

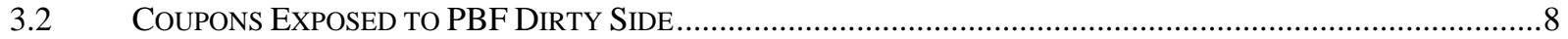

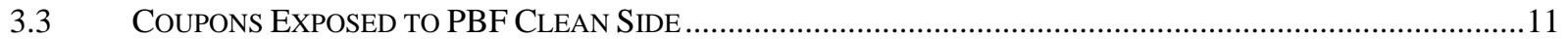

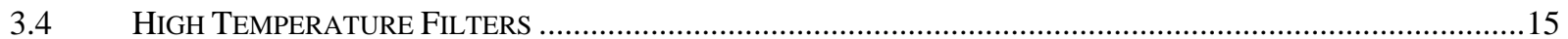

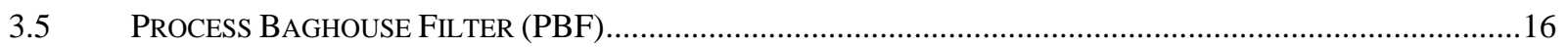

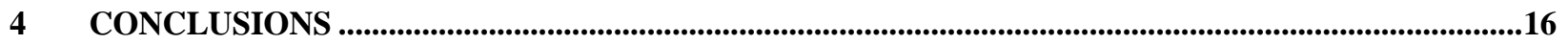

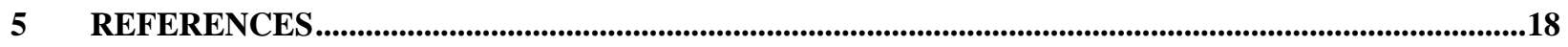




\section{$\underline{\text { List of Tables }}$}

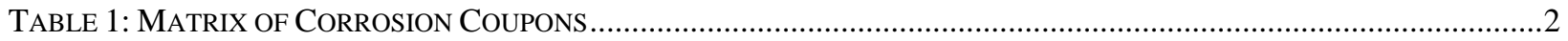

TABLE 2: NoMINAL ALLOY COMPOSITIONS OF COUPONS RECEIVED .......................................................................

TABLE 3: THICKNESS OF WIRES EXPOSED TO THE DMR FREEBOARD ......................................................................

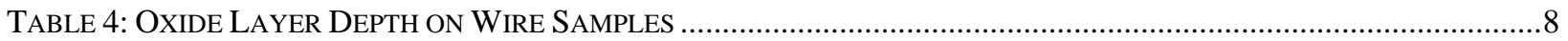

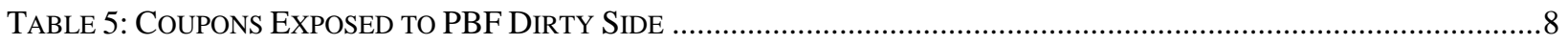

TABLE 6: PENETRATION OF COUPONS EXPOSED TO THE PBF DiRTY SiDE.............................................................11

TABLE 7: COUPONS EXPOSED TO PBF DIRTY SIDE ............................................................................................1

TABLE 8: PENETRATION OF COUPONS EXPOSED TO THE PBF DiRTY SiDE..............................................................15

\section{List of Figures}

FIGURE 1: WIRES EXPOSED TO THE DMR FREEBOARD ....................................................................................

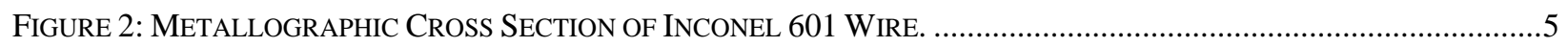

FIGURE 3: METALLOGRAPHIC CROSS SECTION OF INCONEL 617 WIRE ..............................................................6

FIGURE 4: METALLOGRAPHIC CROSS SECTION OF INCONEL 625 WIRE .................................................................6

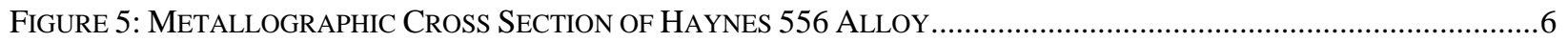

FiguRE 6: METALLOGRAPHIC CROSS SECTION OF HR-160 WIRE ………...............................................................

FiguRE 7: METALLOGRAPHIC CROSS SECTION OF HASTELLOY-X WIRE .....................................................................

FiguRE 8: METALLOGRAPHIC CROSS SCETION OF 53MD (693) WIRE .......................................................................

Figure 9: MEtallographic Cross SeCtion of Coupon 5A- Hastelloy C-22 EXPOSED to PBF DiRTY SidE ..........9

Figure 10: Metallographic Cross SeCtion of Coupon 6C-Hastelloy C-2000 EXPOSED To PBF DiRTy Side.10

Figure 11: METAllographiC CROSS SECTION OF COUPON 7E-HASTELlOY C-276 EXPOSED TO PBF DiRTY SiDE ...10

FIGURE 12: METALLOGRAPHIC CROSS SECTION OF COUPON 8J - AL6XN EXPOSED TO PBF DiRTY SIDE....................10

FiguRE 13: METALlographic CROSS SECTION OF COUPON 9E-317SS EXPOSED TO PBF DiRTY SidE.......................11

Figure 14: Metallographic Cross Section of Coupon 5B- Hastelloy C-22 Exposed to PBF Clean Side ...13

Figure 15: Metallographic Cross Section of Coupon 6D - Hastelloy C-2000 EXPOSED to PBF CleAn SidE

.13

FiguRE 16: METALlOGRAPHIC CROSS SECTION OF COUPON 7F- HASTELloy C-276 EXPOSED TO PBF ClEAN SidE..13

FiguRE 17: METALLOGRAPHIC CROSS SECTION OF COUPON 8G - AL6XN EXPOSED TO PBF CLEAN SidE .................14

Figure 18: Metallographic Cross Section of Coupon 9F- HASTElloy 317 SS EXPOSED to PBF ClEAN SidE 14

Figure 19: METALlographic CrosS SECTION OF Coupon 4H - 316L EXPOSED TO PBF ClEAN SidE ......................14

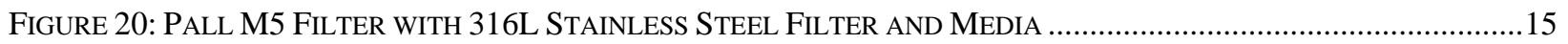

FigURE 21: PALL P3 FILTER WITH INCONEL 600 HARDWARE AND HASTELLOY MEDIA ................................................15

FIGURE 22: 465 FILTER WITH SIC SUPPORT AND ALUMINA MEDIA .....................................................................16

FIGURE 23: PoRVAIR STAINLESS STEEL MICROFILTREX ....................................................................................... 


\section{SUMMARY}

The Savannah River National Laboratory has been contracted to analyze corrosion coupons that are part of the pilotscale testing of the Hazen Thor ${ }^{\mathrm{sm}}$ treatment process. The first phase of the analyses of the HAZEN test coupons was previously completed and corrosion rates were estimated for materials selection. The analyses of the Hazen/TTT CP-2 Test Program corrosion coupons have also been completed and are presented here. The coupons in the CP-2 test program included wire samples that were exposed to the DMR freeboard, coupons exposed to the clean and the dirty (inlet) side of the Process Baghouse Filter (PBF), the PBF itself, and high temperature filters (HTFs). The following are the conclusions from the analyses:

- DMR Freeboard Wires: HR-160 alloy has performed the best on the surface, but the 53MD has the least void formation within the matrix.

- PBF Dirty Side: The nickel based alloys performed better than the superaustenitic stainless steel alloys, which in turn performed better than the traditional stainless steels. However, no significant variances were found within the nickel based alloys, most probably due to the short exposure times and relatively low temperatures.

- PBF Clean Side: No significant variances were found between the performance of the alloys, most probably due to the short exposure times and relatively low temperatures.

- High Temperature Filter: The P3 Hastelloy media filter appears sufficient, while the 465 alumina filter exhibited essentially no degradation.

- $\quad$ Process Baghouse Filter: There was no measurable degradation on the stainless steel mesh filter.

The relatively low temperatures and short exposure times may not be sufficient to elucidate the subtle variances in the corrosion rates of the alloys exposed, as opposed to the phase 1 testing, where variances in corrosion performance were readily measurable. However, these conclusions have been drawn based upon visual examination and microstructural evaluations.

\section{INTRODUCTION}

Pilot scale system/process testing of the $\mathrm{THOR}^{\mathrm{sm}}$ treatment process is being done to support the full-scale process system design, optimization, validation, and permitting activities. In order to validate the selection of the candidate materials of construction for the full-scale production plant, a corrosion test program is being implemented.

As part of the Phase 2 testing, corrosion coupons have been exposed at various locations of the process equipment and thereby subjected to thermal and chemical environments typical of the potentially corrosive process operating conditions. The Savannah River National Laboratory has been contracted to analyze the corrosion of these coupons. The analyses of the corrosion coupons as part of the Hazen/TTT CP-2 test program have been completed and is presented herein.

\subsection{Hazen Test Program of Pilot Process}

The Hazen Test Program included the installation of corrosion coupons throughout various locations of the pilot system.[1] The corrosion mechanisms that take place in each of the process sections are a complex function of environments, temperature and metallurgy of the specific alloys. The following sections provide a summary of each of the environments, potential consequent corrosion mechanisms and the influence of metallurgy/alloy composition on the corrosion performance in each of the process sections. The pilot scale system and process flow diagram is described in detail in Reference 1, and are summarized here for the specific locations of interest for the installed corrosion coupons.[1] The specific locations of interest for this analysis were the freeboard of the denitration and mineralization (DMR) bed, the high temperature filter (HTF), and the process baghouse filter area including the clean side, the filter, and the dirty side. 


\subsection{Corrosion Coupons}

The corrosion testing plan provided installed metal alloy coupons in the process equipment to monitor corrosion during pilot scale testing. The coupons were nominal 2 x 1-in. coupons with a nominal thickness of 0.125 -in. The coupons with their location in the process system, coupon designation, material, serial number, and CMTR\# are listed in Table 1.

Table 1: Matrix of Corrosion Coupons

\begin{tabular}{|c|c|c|}
\hline LOCATION & COUPON & MATERIAL \\
\hline \multirow{7}{*}{ DMR Wire Samples in Freeboard } & & Inconel 601 \\
\hline & & Inconel 617 \\
\hline & & Inconel 625 \\
\hline & & Haynes 556 \\
\hline & & Haynes HR-160 \\
\hline & & Alloy X \\
\hline & & Alloy 693 (53MD) \\
\hline \multirow{6}{*}{ Process Baghouse Filter (PBF) Dirty Side } & $5 \mathrm{~A}$ & Hastelloy C-22 \\
\hline & $6 \mathrm{C}$ & Hastelloy C-2000 \\
\hline & $7 \mathrm{E}$ & Hastelloy C-276 \\
\hline & $8 \mathrm{~J}$ & Al6XN \\
\hline & $9 \mathrm{E}$ & $317 \mathrm{SS}$ \\
\hline & $4 \mathrm{G}$ & 316L SS \\
\hline \multirow{3}{*}{ High Temperature Filter (HTF) } & & Alloy X \\
\hline & & $316 \mathrm{~L}$ \\
\hline & & $\mathrm{SiC}$ \\
\hline PBF - Sintered Filter Material Media & & Porvair \\
\hline \multirow{6}{*}{ PBF Clean Side } & $5 B$ & Hastelloy C-22 \\
\hline & $6 \mathrm{D}$ & Hastelloy C-2000 \\
\hline & $7 F$ & Hastelloy C-276 \\
\hline & $8 G$ & Al6XN \\
\hline & $9 \mathrm{~F}$ & 317 SS \\
\hline & $4 \mathrm{H}$ & 316L SS \\
\hline
\end{tabular}

The compositions of each of the materials per the materials certificates are shown in Table 2. 
Table 2: Nominal Alloy Compositions of Coupons Received

\begin{tabular}{|c|c|c|c|c|c|c|c|c|c|c|c|c|c|c|c|c|}
\hline \multirow[t]{2}{*}{ Material } & \multicolumn{16}{|c|}{ Compositions } \\
\hline & $\mathbf{F e}$ & $\mathrm{Cr}$ & $\mathrm{Ni}$ & Co & Mo & $\mathbf{W}$ & Mn & Ta & $\mathrm{Cu}$ & $\mathbf{T i}$ & Si & $\mathbf{N}$ & Al & $\mathrm{C}$ & $\mathbf{Z r}$ & La \\
\hline $\begin{array}{l}\text { Filler Metal } \\
\text { Inconel 601 }^{\mathrm{a}}\end{array}$ & 16 & 24 & 58 & .05 & & & .22 & & 0.16 & & .29 & & 1.59 & 0.03 & & \\
\hline 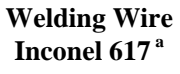 & 1.4 & 21.3 & 53.9 & 12 & 9.4 & & .1 & & .04 & & 0.2 & & 1.0 & 0.14 & & \\
\hline $\begin{array}{l}\text { Welding Wire } \\
\text { Inconel } 625^{\mathrm{a}}\end{array}$ & .46 & 21.79 & 64.82 & & 8.9 & & & & 0.03 & 0.25 & & & 0.29 & & & \\
\hline Haynes $556^{\mathrm{a}}$ & 31 & 21.97 & 21.83 & 18.14 & 2.92 & 2.50 & .94 & & & & 0.44 & & 0.28 & 0.1 & 0.17 & \\
\hline $\begin{array}{c}\text { Haynes HR- } \\
1^{160^{a}}\end{array}$ & 0.1 & 27.6 & 37.89 & 30.5 & 0.08 & & 0.45 & & & 0.47 & 2.69 & & 0.07 & 0.04 & & \\
\hline 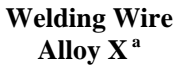 & $\begin{array}{l}18 . \\
84\end{array}$ & 20.99 & 49.8 & 1.26 & 8.29 & 0.56 & 0.06 & & & & .08 & & & 0.07 & & \\
\hline $\begin{array}{l}\text { Inconel Filler } \\
\text { Metal 53MD }^{a}\end{array}$ & 3.2 & 28.83 & 63.66 & & & & 0.04 & & & 0.3 & .23 & & 3.01 & 0.02 & & \\
\hline $\begin{array}{c}\text { Hastelloy } \\
{\text { C- } 22^{\mathrm{b}}}^{\mathrm{b}}\end{array}$ & 3 & 22 & 56 & 2.5 & 13 & 3 & 0.5 & & & & 0.08 & & & & & \\
\hline $\begin{array}{l}\text { Hastelloy } \\
\text { C-2000 }\end{array}$ & 3 & 23 & 59 & 2 & 16 & & & & 1.6 & & & & & & & \\
\hline $\begin{array}{c}\text { Hastelloy } \\
\text { C-276 }\end{array}$ & & & & & & & & & & & & & & & & \\
\hline $\operatorname{AL6XN}^{b}$ & Bal & 20 & 24 & & 6.2 & & 0.4 & & 0.2 & & 0.4 & 0.22 & & 0.02 & & \\
\hline $317 \mathrm{SS}^{\mathrm{b}}$ & Bal & $18-20$ & 11-14 & & $3-4$ & & 2 & & & & 0.75 & & & 0.8 & & \\
\hline $316 \mathrm{~L} \mathrm{SS}^{\mathrm{b}}$ & Bal & 17 & 12 & & 2.5 & & 2 & & & & 1 & & & 0.03 & & \\
\hline
\end{tabular}

(a) Composition per materials certificates

(b) Nominal composition

The wire samples were exposed to the DMR freeboard to determine the welding materials of construction. The Inconel 601 is a general purpose engineering Ni-Cr-Fe alloy with resistance to high temperature oxidation. The Inconel 617 is a solid-solution strengthened, nickel-chromium-cobalt-molybdenum alloy with a combination of high-temperature strength (from cobalt and molybdenum) and oxidation resistance due to the high chromium and nickel content. The Inconel 625 is a nickel-chromium-molybdenum alloys which has excellent fabricability and strength, and corrosion resistance. The Inconel 625 is known to be especially resistant to carburization. The Inconel 693 alloy is a nickel-chromium-aluminum alloys that is known to be resistant to metal dusting. Alloy $\mathrm{X}$ is a precipitation-hardenable nickel-chromium alloy used for its corrosion and oxidation resistance and high temperature strength.

The Haynes 556 is an iron-nickel-chromium-cobalt alloy, while the HR-160 is a solid-solution strengthened nickelcobalt-chromium-silicon alloy. The Haynes 556/HR-160 nickel based alloys are inherently resistant to many acids and alkalis, thereby providing a good basis for development of specialized alloys. The Haynes 556 alloy is considered a Fe-based alloy with significant alloying additions of cobalt and some molybdenum. Each of these alloys has specific alloying components that lead to corrosion resistance in specific environments.[2] The Haynes HR-160 alloy has significant amounts of chromium, nickel and cobalt, and is typically thought to be most resistant of the alloys exposed to sulfidizing environments. The Haynes 556 alloy is typically recommended for resistance to carburizing and molten salt chloride containing environments.

The standard 316L stainless steel alloy has additions of chromium and nickel, while maintaining a low carbon 
content to prevent the formation of carbides, and increasing the resistance to intergranular attack. In addition, molybdenum is added to further increase the resistance to intergranular attack and general corrosion. The 317 stainless steel and the AL6XN alloys have progressively increasing chromium, nickel, and molybdenum concentrations thereby increasing their corrosion resistance. The Hastelloy C-22 is a nickel-chromiummolybdenum-tungsten alloy with good weldability and exhibits corrosion resistance in a wide variety of environments and specifically as a weld-filler material. The Hastelloy C-2000 is a nickel-chromium-molybdenum alloy with a copper content to provide resistant to both oxidizing and reducing environments. The Hastelloy C-276 alloys is nickel-molybdenum-chromium alloy that exhibits resistance to localized corrosion in oxidizing and reducing environments, but may need C-22 filler materials as a weld material to increase the as-welded corrosion resistance.

\section{RESULTS}

All coupons and wires were initially visually inspected and photographed. Deposits were analyzed with x-ray diffraction (XRD) and/or x-ray fluorescence (XRF). The initial thicknesses were measured using a micrometer. Additional analysis was completed on select coupons after sectioning, grinding and polishing. The wires will also be analyzed microstructurally and the thickness will be measured using a traveling stage microscope.

\subsection{Wire Coupons Exposed to DMR Freeboard}

The coupons exposed to the DMR are possibly subject to ash-type corrosion due to the mixed waste form, sulfidation during the high temperature operation in a reducing environment, and any modes of the down-time corrosion. Due to the complex nature of the waste, any of these corrosion mechanisms are expected to be exacerbated by the influence of the halogens.

The wires exposed to the DMR freeboard are expected to be exposed to the volatilized constituents from the DMR bed. The availability of the oxygen and process deposits in the freeboard may lead to higher corrosion rates than the coupons exposed to the DMR bed. The nominal average temperature was $610^{\circ} \mathrm{C} \pm 40^{\circ} \mathrm{C}$. The coupon rack had significant process deposits as shown in Figure 1. There was evidence of significant process deposits on the coupons, which are expected to be oxides, sodium alumino-silicates, and sulfates.[3]

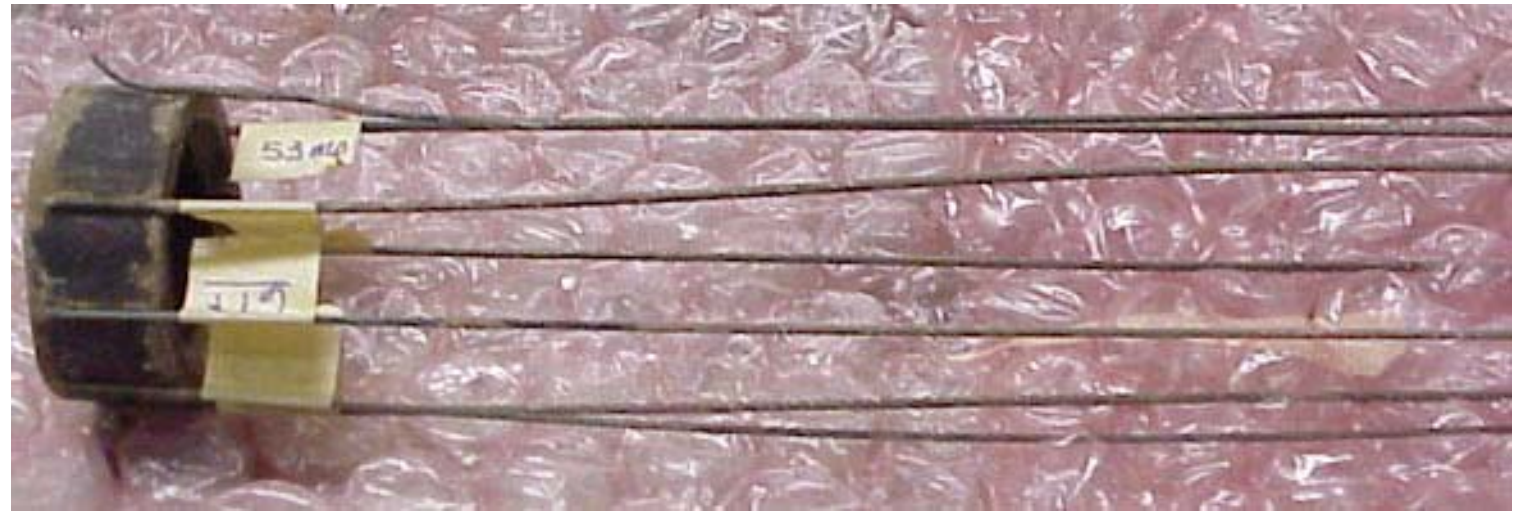




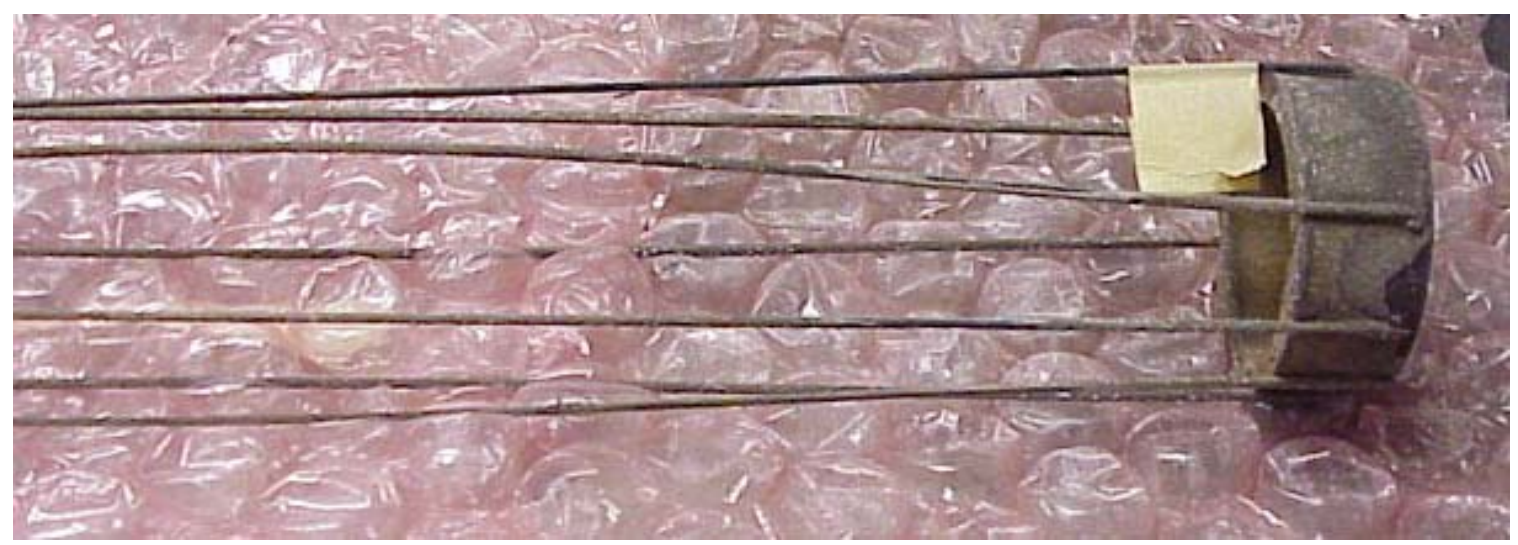

Figure 1: Wires Exposed to the DMR Freeboard

The DMR coupons were exposed for a total time of 180 hours nominally at $600^{\circ} \mathrm{C}$, in addition to several days at elevated temperatures, i.e $100^{\circ} \mathrm{C}$ to $225^{\circ} \mathrm{C}$. The thickness of the wires was measured to determine the general corrosion of the coupons. The thickness measurements do not reveal any differences in corrosion performance.

Table 3: Thickness of Wires Exposed to the DMR Freeboard

\begin{tabular}{|c|c|c|}
\hline Alloy & Init Thick (in.) & Final Thick (in.) \\
\hline Inconel 601 & 0.061 & 0.060 \\
\hline Inconel 617 & 0.061 & 0.061 \\
\hline Inconel 625 & 0.062 & 0.062 \\
\hline Haynes 556 & 0.062 & 0.061 \\
\hline Haynes HR-160 & 0.062 & 0.061 \\
\hline Alloy X & 0.062 & 0.062 \\
\hline 53MD (693) & 0.090 & 0.093 \\
\hline
\end{tabular}

Previous analysis of alloys exposed to the DMR freeboard indicated that the sulfidation during the reducing high temperature operation may be the most active corrosion mechanism. In contrast to the previous test coupons, the temperature in the DMR freeboard remained below $250^{\circ} \mathrm{C}$ which would not be high enough to initiate sulfidation in these alloys. Microstructural examination of the wires will determine any variances in corrosion rates for the short exposure times. Metallographic analyses were completed for the wire coupons and are shown in Figure 2 - 8.
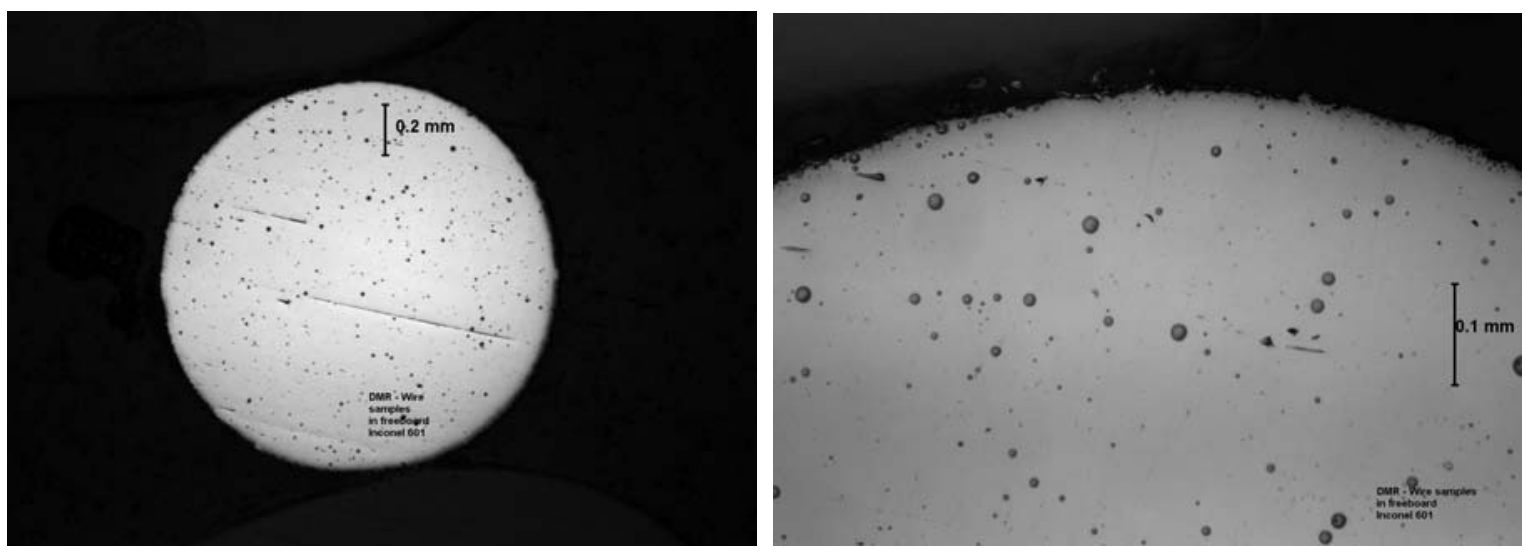

Figure 2: Metallographic Cross Section of Inconel 601 Wire. 

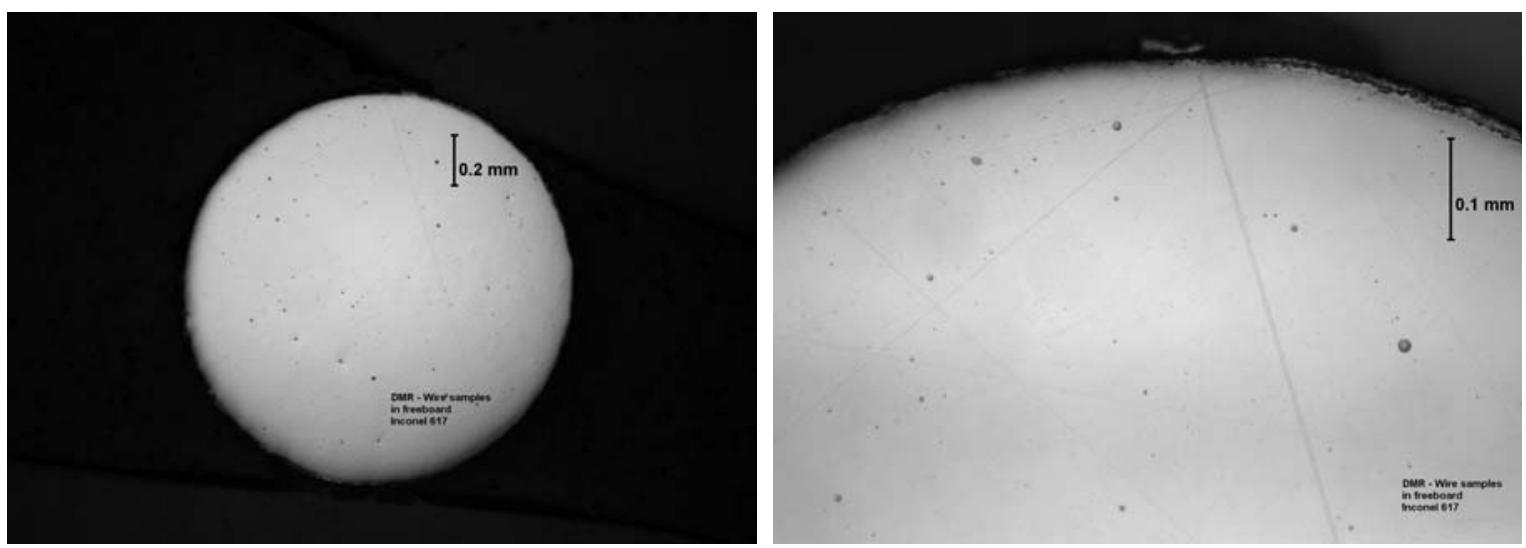

Figure 3: Metallographic Cross Section of Inconel 617 Wire
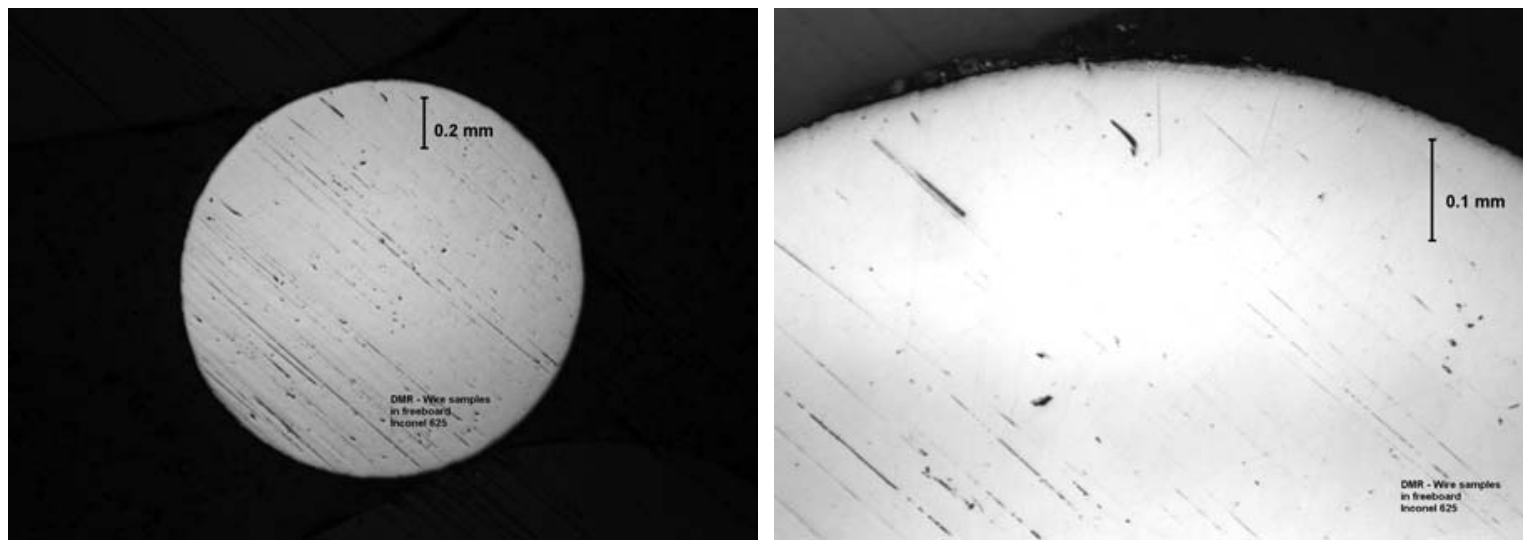

Figure 4: Metallographic Cross Section of Inconel 625 Wire
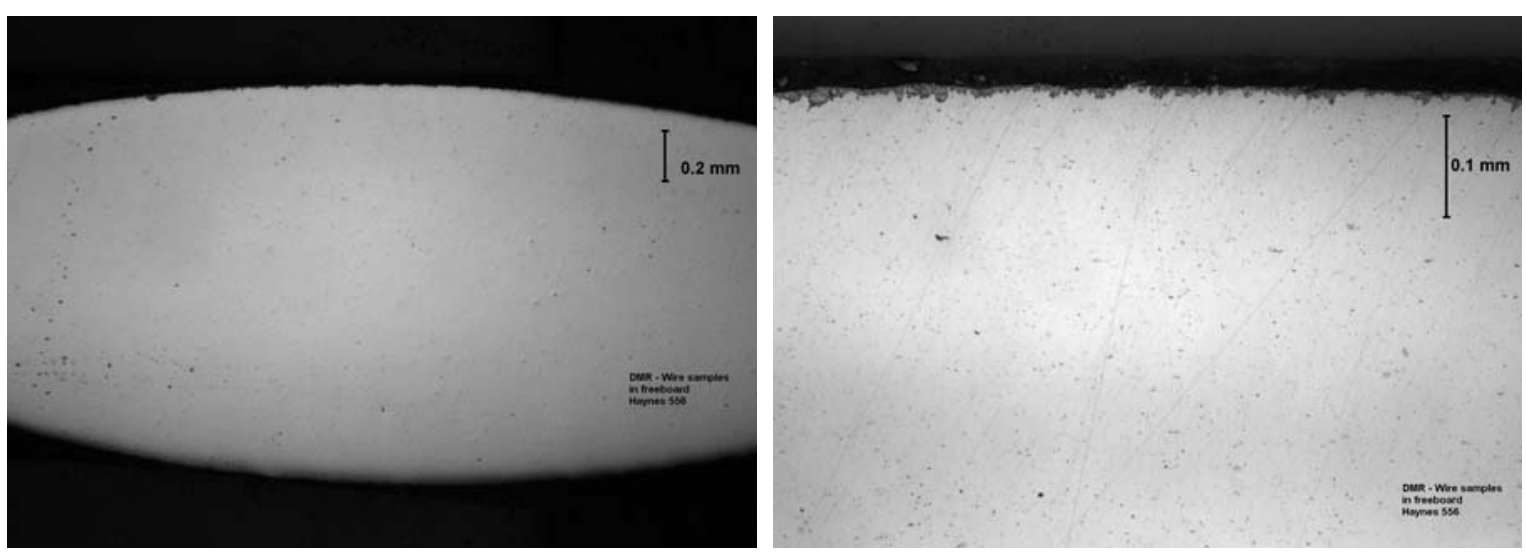

Figure 5: Metallographic Cross Section of Haynes 556 Alloy 

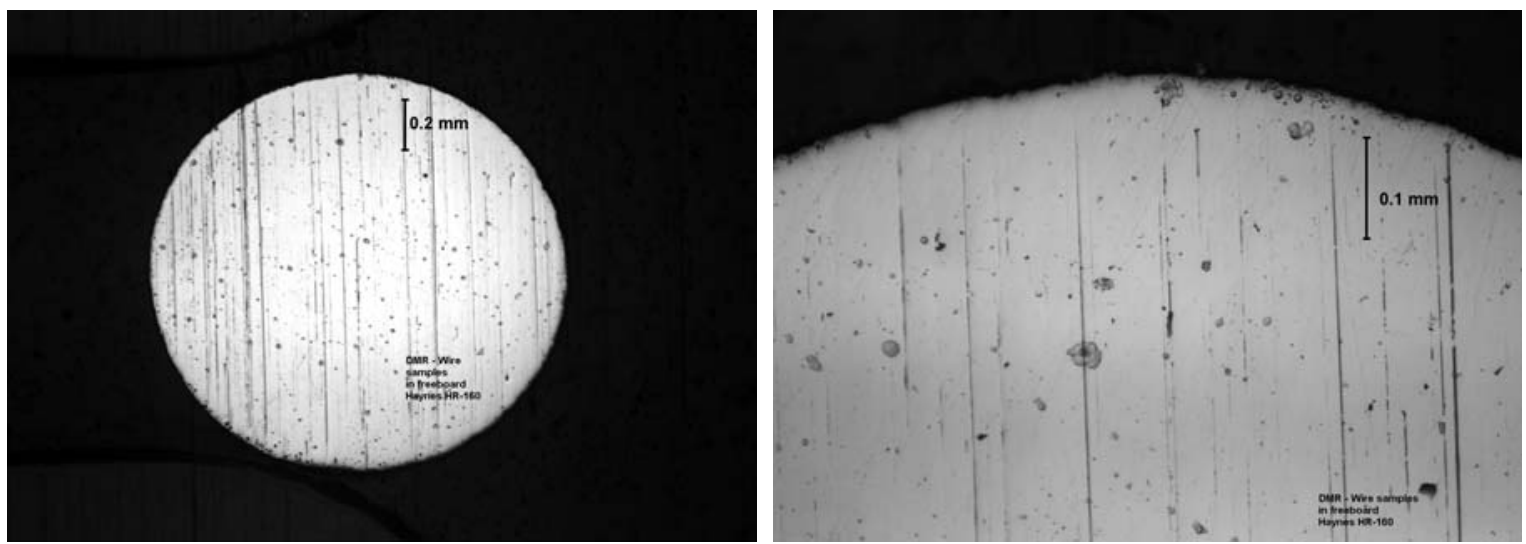

Figure 6: Metallographic Cross Section of HR-160 Wire
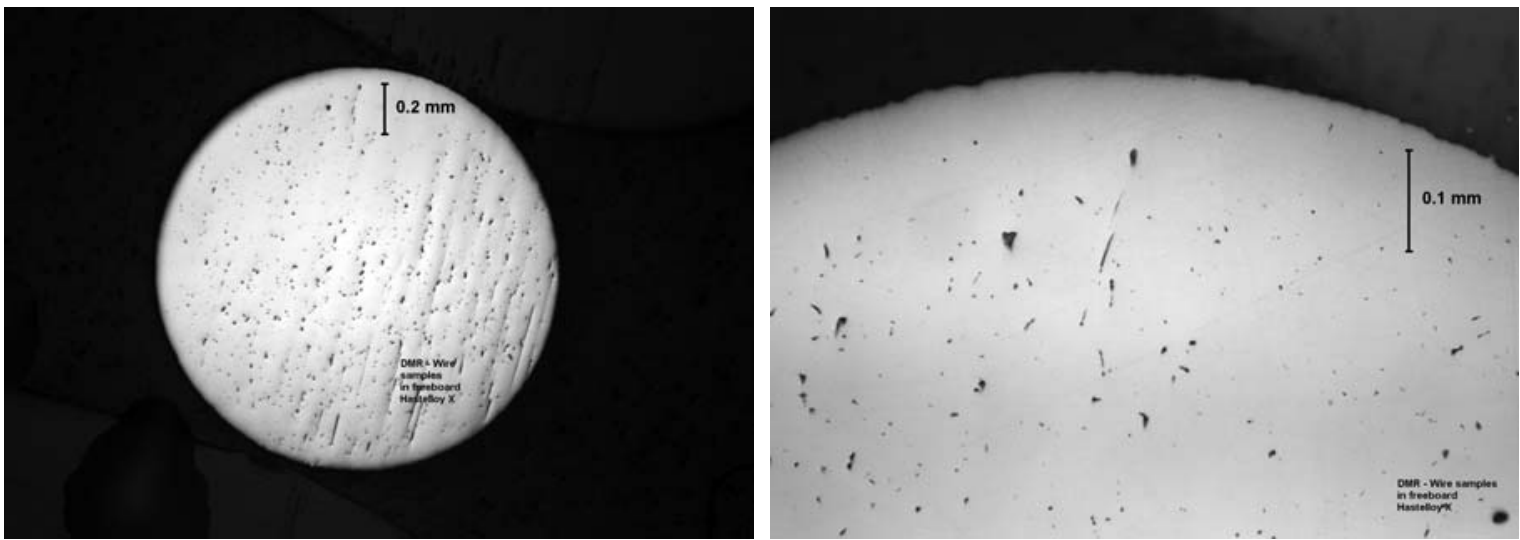

Figure 7: Metallographic Cross Section of Hastelloy-X Wire
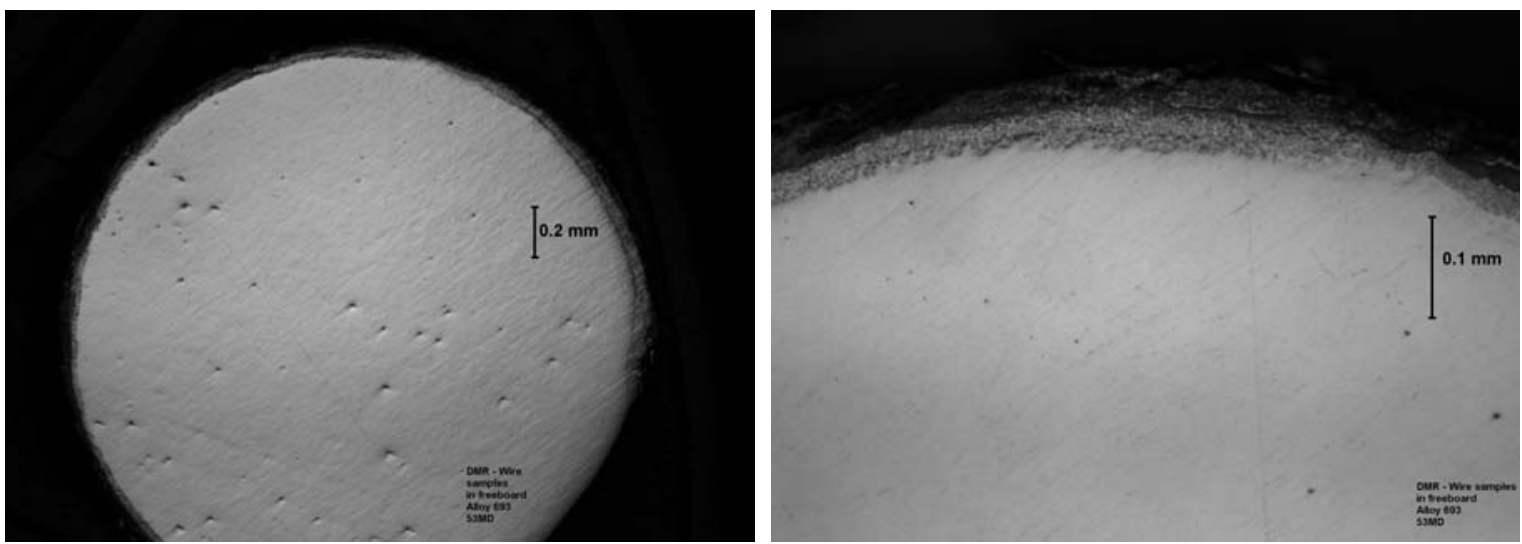

Figure 8: Metallographic Cross Scetion of 53MD (693) Wire

The metallographic analysis indicates that the 53MD wire has a stable oxide film on the surface and also indicates the least amount of void formation within the matrix. The 53MD wire also had the thickest oxide layer, but this may also be due to the exposed surface area being larger than the other wires, that were thinner. The oxide layer depth was estimated using the calibrated micrographs and are shown in Table 4. All of the alloys performed similarly with the exception of the 53MD alloy having the largest oxide layer. 
Table 4: Oxide Layer Depth on Wire Samples

\begin{tabular}{|l|c|c|}
\hline \multicolumn{1}{|c|}{ Location } & Alloy & Oxide Depth $(\boldsymbol{\mu m})$ \\
\hline DMR Freeboard & Inconel 601 & N/A \\
\hline (600C) & Inconel 617 & 14 \\
\hline 180 hours & Inconel 625 & 10 \\
\hline & Haynes 556 & 10 \\
\hline & Haynes HR-160 & 10 \\
\hline & Alloy X & 10 \\
\hline & 53MD (693) & 45 \\
\hline
\end{tabular}

It is difficult to draw quantitative conclusions from these exposures because of the short duration and the relatively low temperature of the test. However, it appears that the HR-160 alloy has performed the best on the surface, but the 53MD has the least void formation within the matrix.

\subsection{Coupons Exposed to PBF Dirty Side}

The process gas stream is filtered in the Process Baghouse Filter (PBF). The coupons that were exposed to the process baghouse filter are also resistant to high temperature corrosion mechanisms. The coupons exposed to the PBF were a standard 316L stainless steel, a 317 stainless steel, an AL6XN superaustentic stainless steel alloy, and several nickel-based alloys. The corrosion coupons in the PBF section were mounted on the dirty side of the filter. The nominal temperature in this region was $150^{\circ} \mathrm{C} \pm 10^{\circ} \mathrm{C}$. The photographs of the coupons are shown in Table 5 . The process deposits on the coupons were mostly graphite and mercurous sulfate.

Table 5: Coupons Exposed to PBF Dirty Side

\begin{tabular}{|c|c|c|l|}
\hline COUPON & MATERIAL & AS-RECEIVED & \multicolumn{1}{|c|}{ XRD DEPOSIT ANALYSIS } \\
\hline \multirow{5}{*}{$5 \mathrm{~A}$} & $\begin{array}{c}\text { Hastelloy C- } \\
22\end{array}$ & & Graphite \\
$\mathrm{Hg}_{2} \mathrm{SO}_{4}$ (mercury sulfate)
\end{tabular}




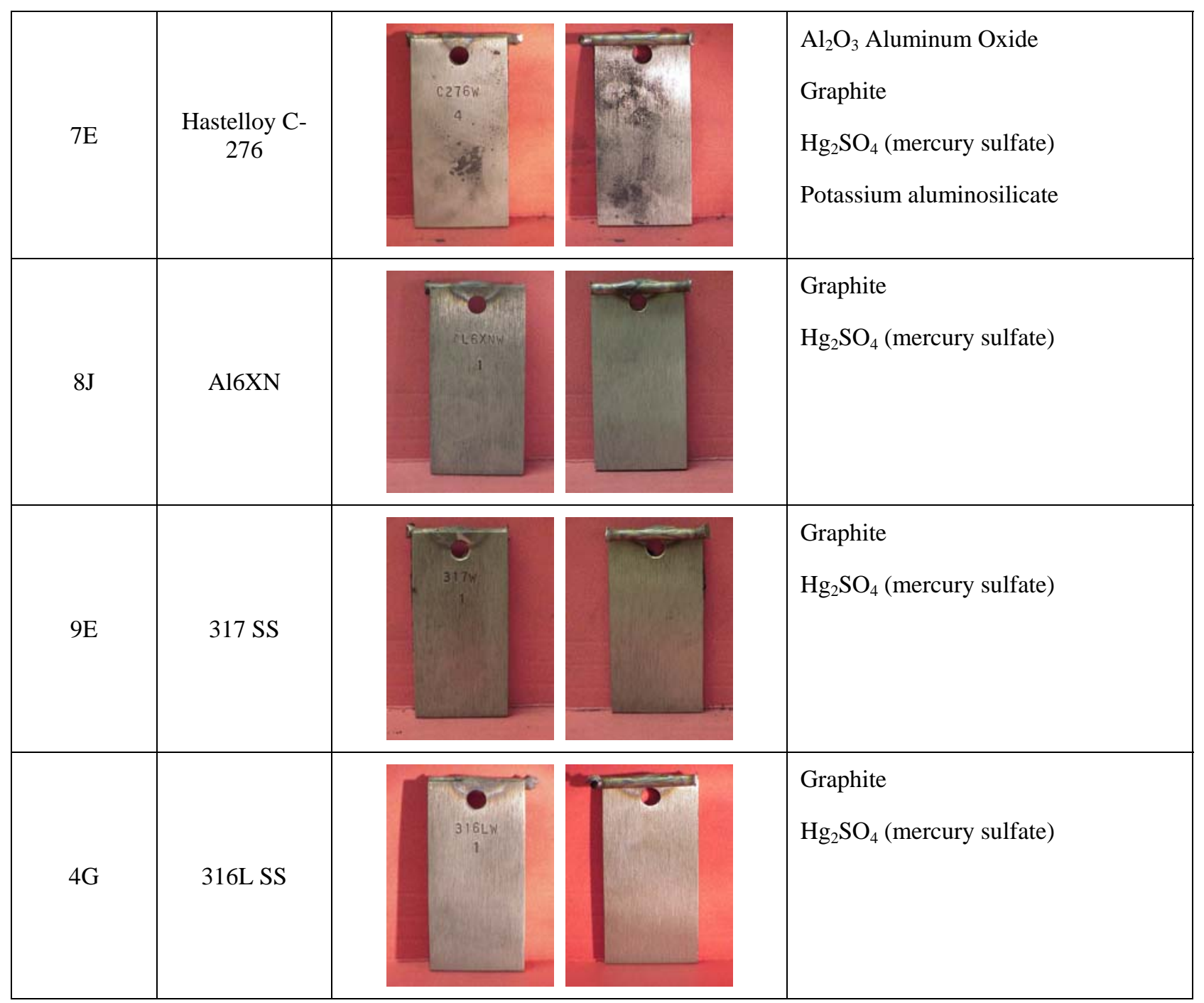

Metallographic analyses of these coupons were completed and are shown in Figure 9 - 13. The metallographic analysis indicates pervasive pitting with little intergranular attack beyond the pitting front.
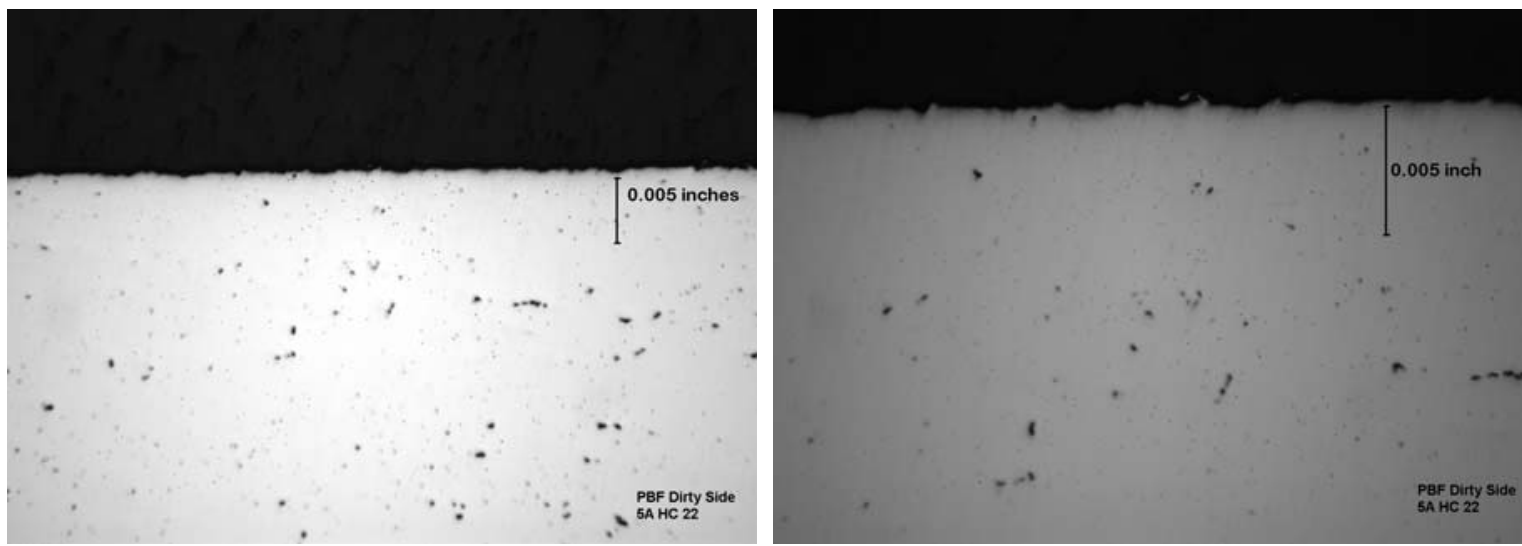

Figure 9: Metallographic Cross Section of Coupon 5A- Hastelloy C-22 Exposed to PBF Dirty Side 

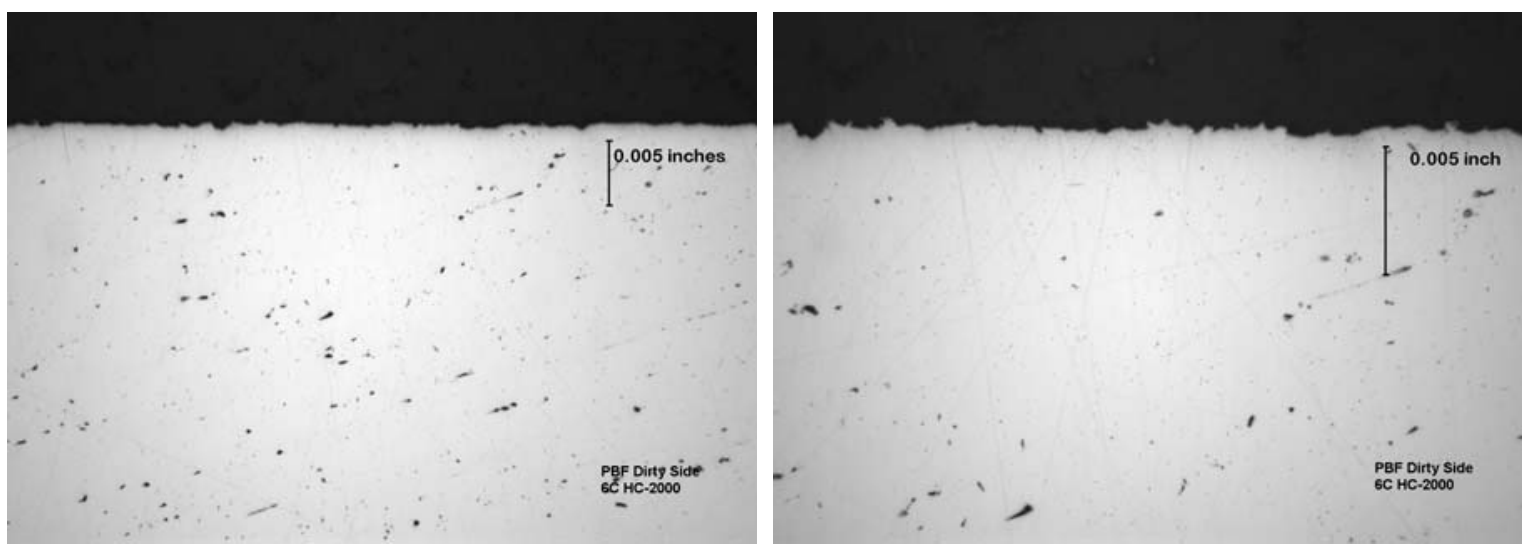

Figure 10: Metallographic Cross Section of Coupon 6C-Hastelloy C-2000 Exposed to PBF Dirty Side
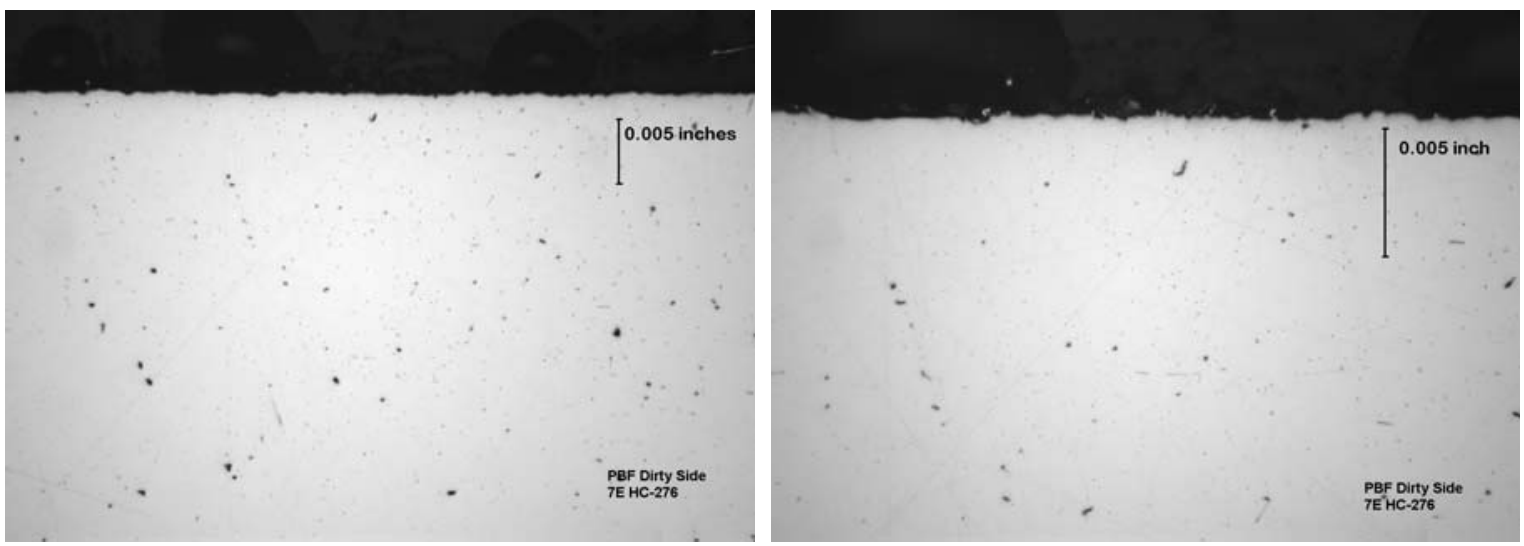

Figure 11: Metallographic Cross Section of Coupon 7E-Hastelloy C-276 Exposed to PBF Dirty Side
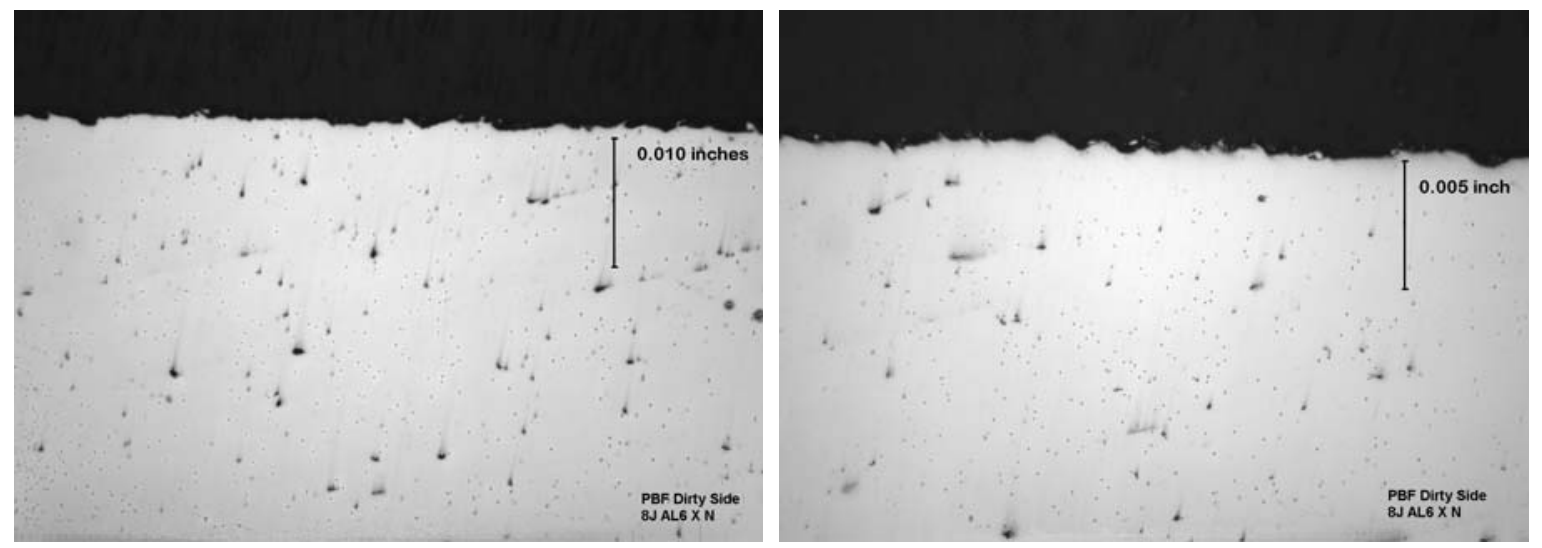

Figure 12: Metallographic Cross Section of Coupon 8J - AL6XN Exposed to PBF Dirty Side 

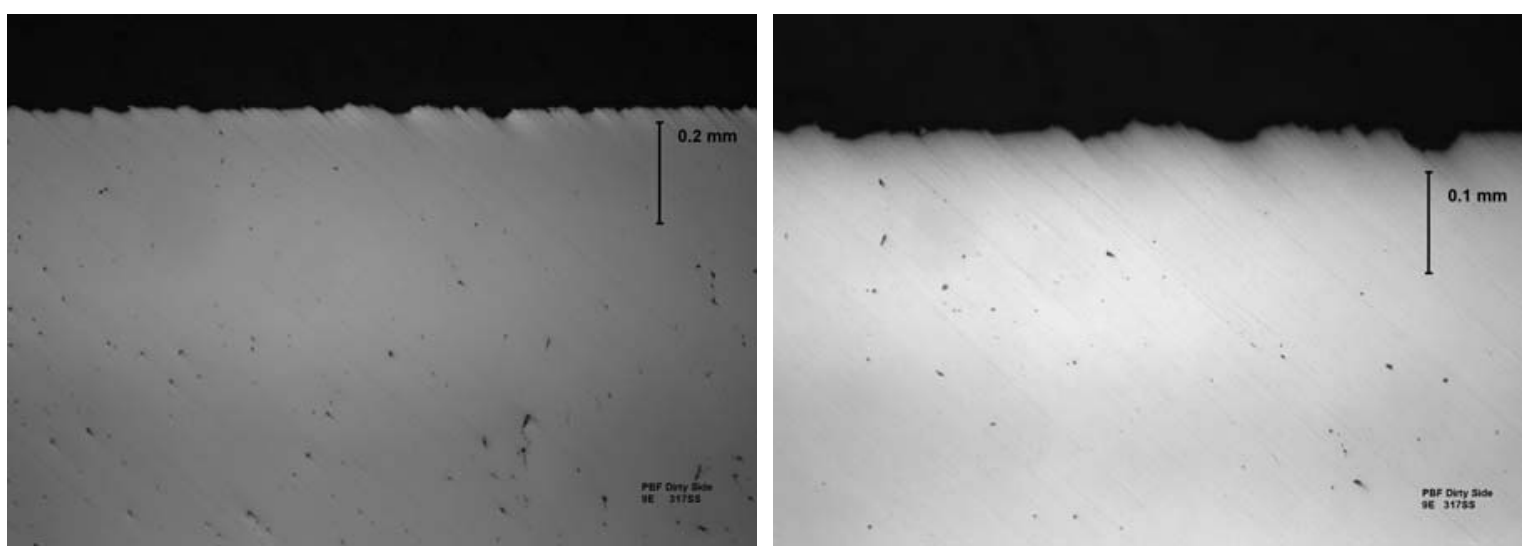

Figure 13: Metallographic Cross Section of Coupon 9E-317SS Exposed to PBF Dirty Side

The nickel based alloys performed better than the superaustenitic stainless steel alloys, which in turn performed better than the traditional stainless steels. The depth of penetration was estimated using the calibrated micrographs and are shown in Table 6. The temperatures in the PBF remained below $160^{\circ} \mathrm{C}$ and many of the high temperature corrosion mechanisms are not significant in this range. As such, the down-time corrosion or ash-related corrosion is potentially more significant for these coupons.

Table 6: Penetration of Coupons Exposed to the PBF Dirty Side

\begin{tabular}{|c|c|c|c|c|}
\hline $\begin{array}{c}\text { Location } \\
\text { Coupon }\end{array}$ & Alloy & $\begin{array}{c}\text { Penetration } \\
\text { Depth }(\boldsymbol{\mu m})\end{array}$ & $\begin{array}{c}\text { Penetration } \\
\text { Rate }(\boldsymbol{\mu m} / \mathbf{h r})\end{array}$ \\
\hline & 5A & Hastelloy C-22 & 18 & 0.06 \\
\hline & 6C & Hastelloy C-2000 & 15 & 0.05 \\
\hline $\mathbf{3 0 4 . 5}$ & 7E & Hastelloy C-276 & 13 & 0.04 \\
\hline & $\mathbf{8 J}$ & Al6XN & 53 & 0.17 \\
\hline & 9E & $\mathbf{3 1 7}$ SS & 25 & 0.08 \\
\hline
\end{tabular}

\subsection{Coupons Exposed to PBF Clean Side}

Coupons were also exposed to the clean side of the PBF. The nominal temperature in this region was $150^{\circ} \mathrm{C} \pm 0^{\circ} \mathrm{C}$. The photographs of the coupons are shown in Table 7. The coupons showed pervasive corrosion but not as extensive as other sections, based upon the visibility of the machining marks. Process deposits were determined with XRF and XRD and showed primarily alloying elements with mercurous sulfate deposits also present but in very minor quantities.

Table 7: Coupons Exposed to PBF Dirty Side

\begin{tabular}{|c|c|c|}
\hline COUPON & MATERIAL & AS-RECEIVED \\
\hline & & 0 \\
5B & Hastelloy C-22 & \\
& & \\
\hline
\end{tabular}




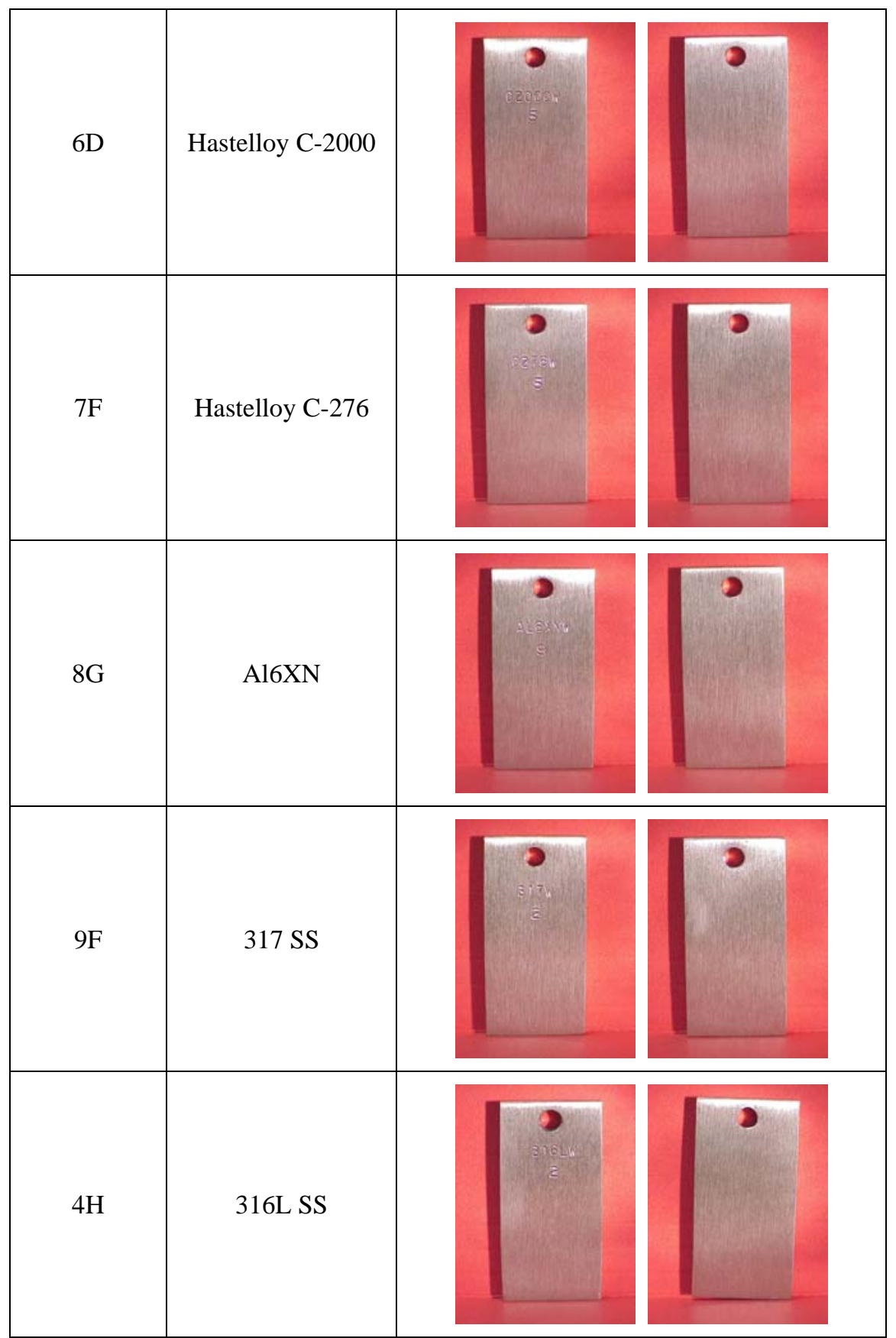

Metallographic analyses for the coupons have been completed and are shown in Figure 14 - 19. 

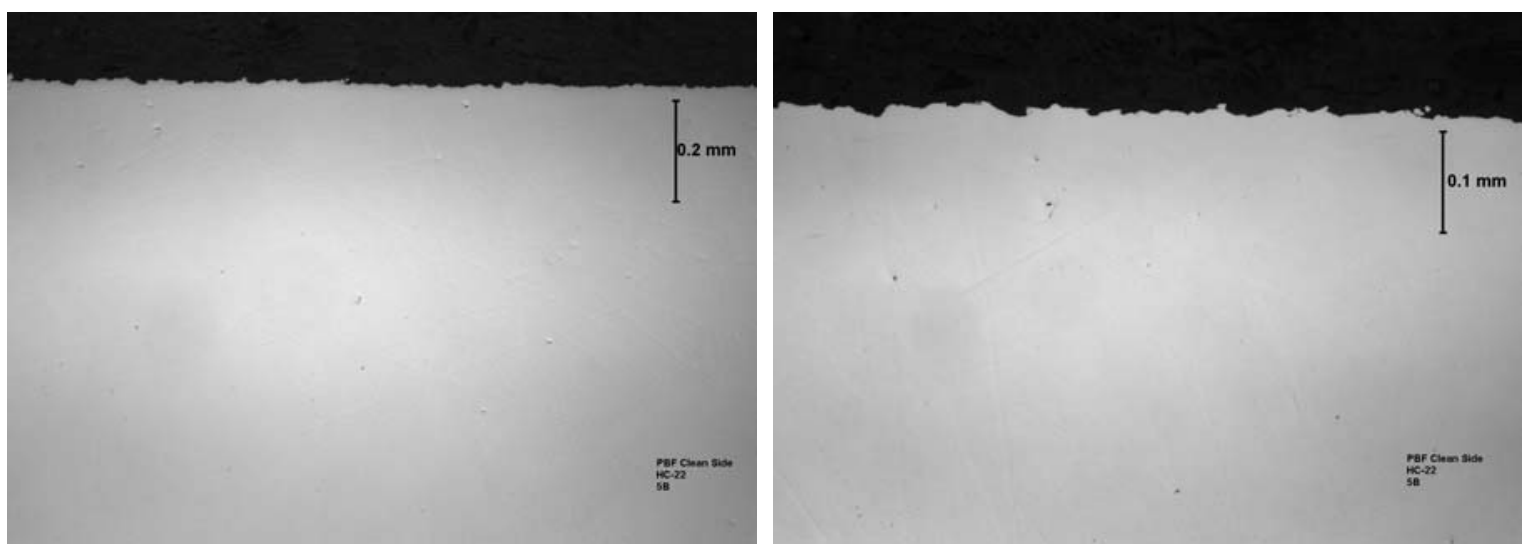

Figure 14: Metallographic Cross Section of Coupon 5B- Hastelloy C-22 Exposed to PBF Clean Side
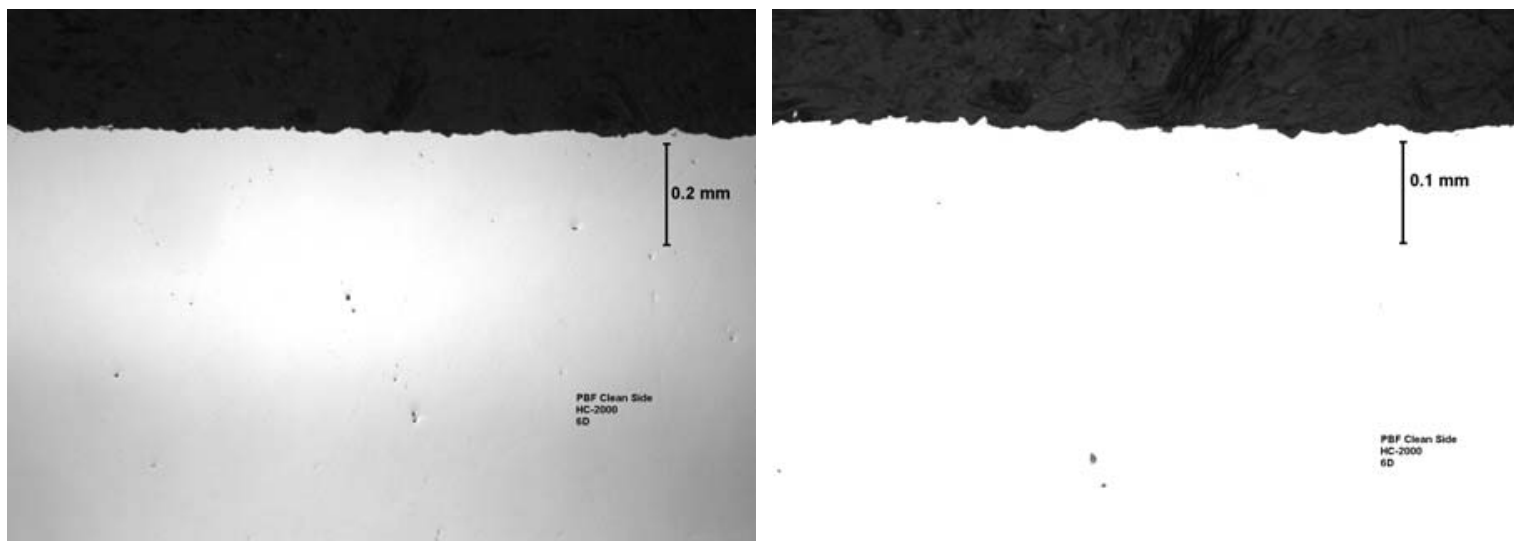

Figure 15: Metallographic Cross Section of Coupon 6D - Hastelloy C-2000 Exposed to PBF Clean Side
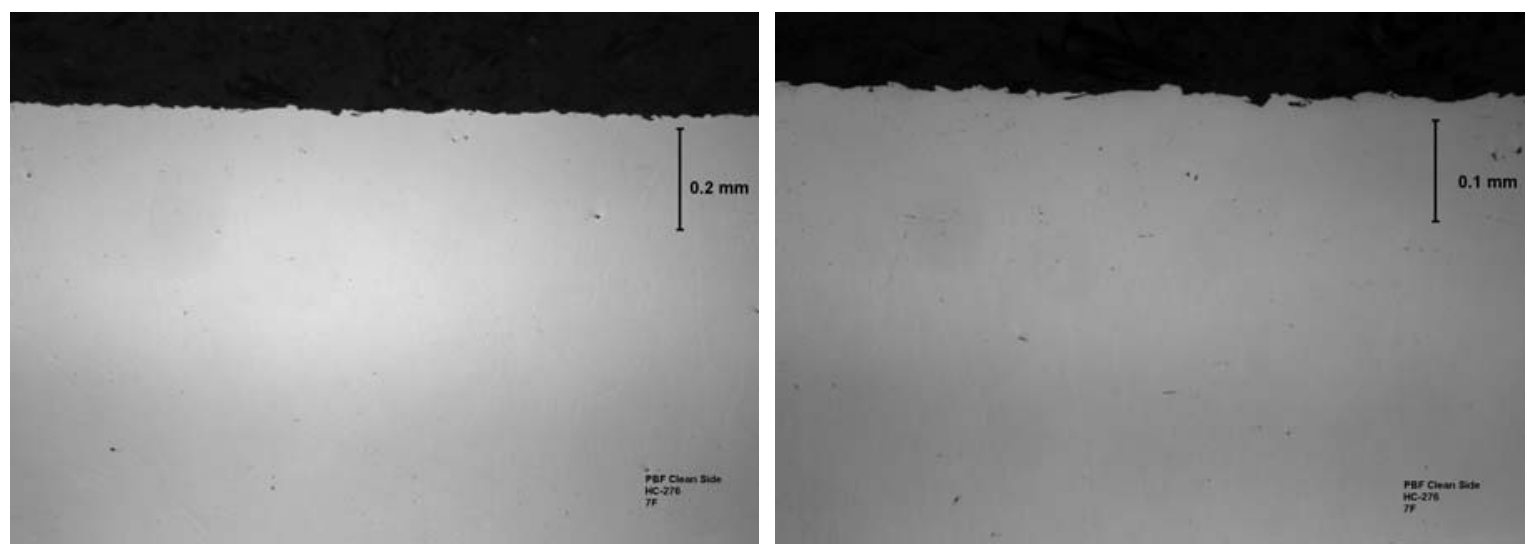

Figure 16: Metallographic Cross Section of Coupon 7F- Hastelloy C-276 Exposed to PBF Clean Side 

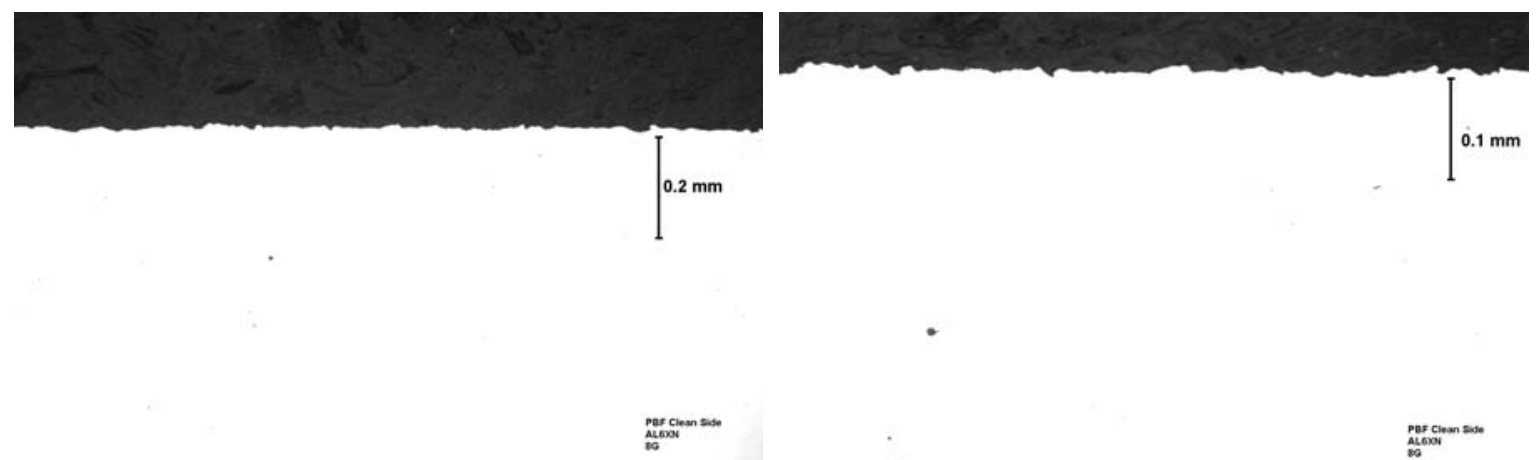

Figure 17: Metallographic Cross Section of Coupon 8G - AL6XN Exposed to PBF Clean Side
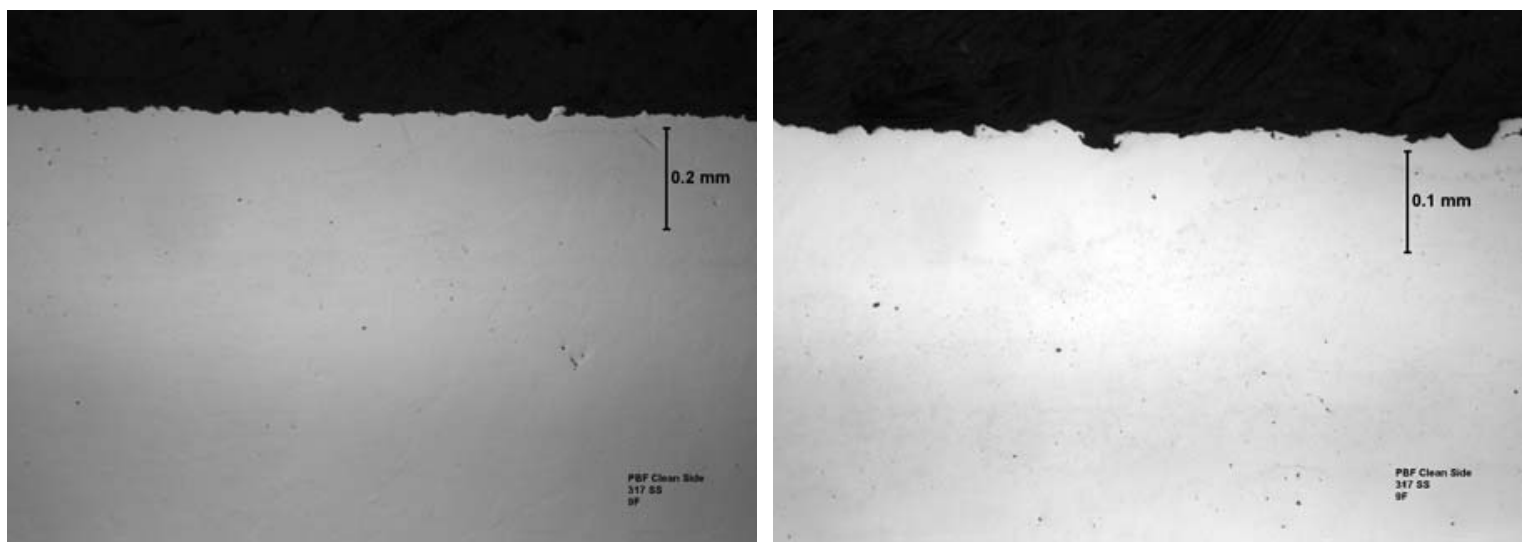

Figure 18: Metallographic Cross Section of Coupon 9F- Hastelloy 317 SS Exposed to PBF Clean Side
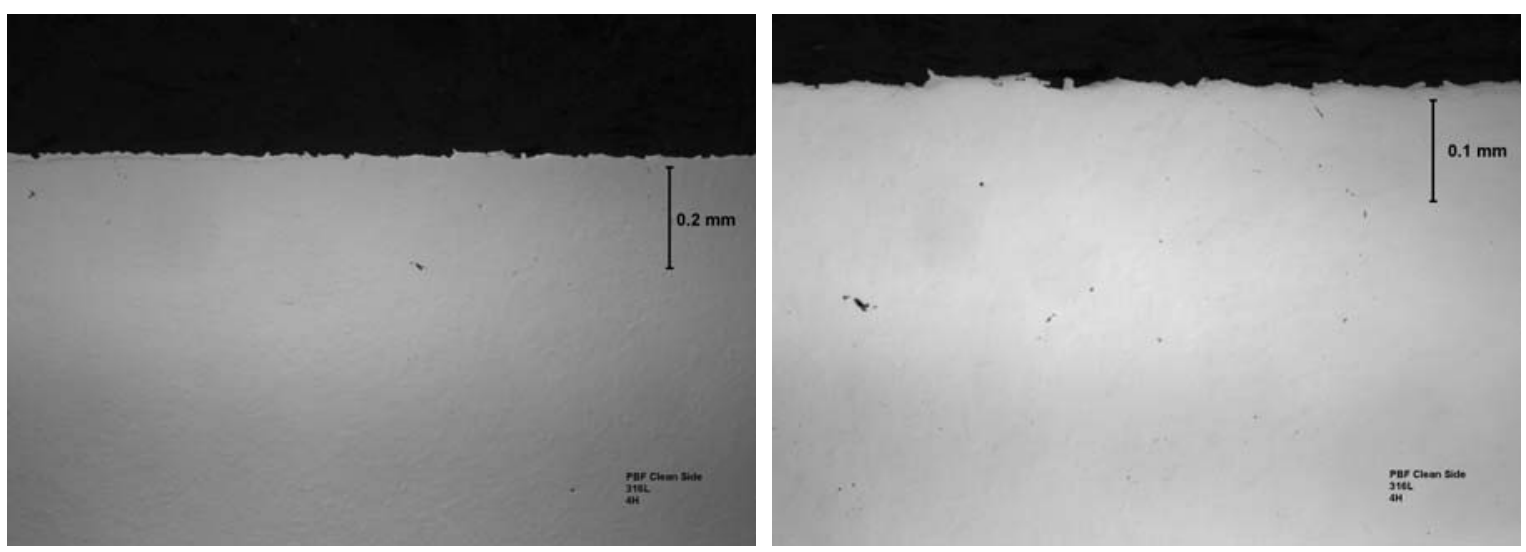

Figure 19: Metallographic Cross Section of Coupon 4H - 316L Exposed to PBF Clean Side

None of the coupons exposed to the PBF clean side exhibited intergranular attack or internal void formation. Preliminary analysis of the microstructures indicates that performance of alloys was similar with the nickel based alloys performing slightly better than the stainless steels. The depth of penetration was estimated using the calibrated micrographs and are shown in Table 6. The temperatures in the PBF remained below $160^{\circ} \mathrm{C}$ and many of the high temperature corrosion mechanisms are not significant in this range. As such, the down-time corrosion or ash-related corrosion is potentially more significant for these coupons. 
Table 8: Penetration of Coupons Exposed to the PBF Dirty Side

\begin{tabular}{|c|c|c|c|c|}
\hline $\begin{array}{c}\text { Location } \\
\text { Coupon }\end{array}$ & Alloy & $\begin{array}{c}\text { Penetration } \\
\text { Depth }(\boldsymbol{\mu m})\end{array}$ & $\begin{array}{c}\text { Penetration } \\
\text { Rate }(\boldsymbol{\mu m} / \mathbf{h r})\end{array}$ \\
\hline PBF Dirty Side & 5A & Hastelloy C-22 & 11 & 0.04 \\
\hline & 6C & Hastelloy C-2000 & 18 & 0.06 \\
\hline $\mathbf{3 0 4 . 5}$ & 7E & Hastelloy C-276 & 18 & 0.06 \\
\hline & 8J & Al6XN & 16 & 0.05 \\
\hline & 9E & 317 SS & 21 & 0.07 \\
\hline
\end{tabular}

\subsection{High Temperature Filters}

The process gas from the DMR, consisting mostly of steam, nitrogen, carbon dioxide, and hydrogen, with small amounts of carbon monoxide, $\mathrm{NO}_{\mathrm{x}}$, short-chained organics, and acidic gases, is filtered through the High Temperature Filter (HTF). This filter removes the finely divided product solids and charcoal fines that elutriate out of the DMR with the process gas stream. The three filters that were tested in the CP-2 tests were the following:

1. $\quad$ Pall M5 filter: 316L hardware and media

2. $\quad$ Pall P3 filter: Inconel 600 hardware and Hastelloy X media

3. $465 \mathrm{SiC}$ support with alumina media

The exposures were 113 hours at temperatures between 200 and $350^{\circ} \mathrm{C}$, and 177 hours at temperatures between 350 and $425^{\circ} \mathrm{C}$. The photographs of the three filters following the exposures are shown in Figure $20-22$.

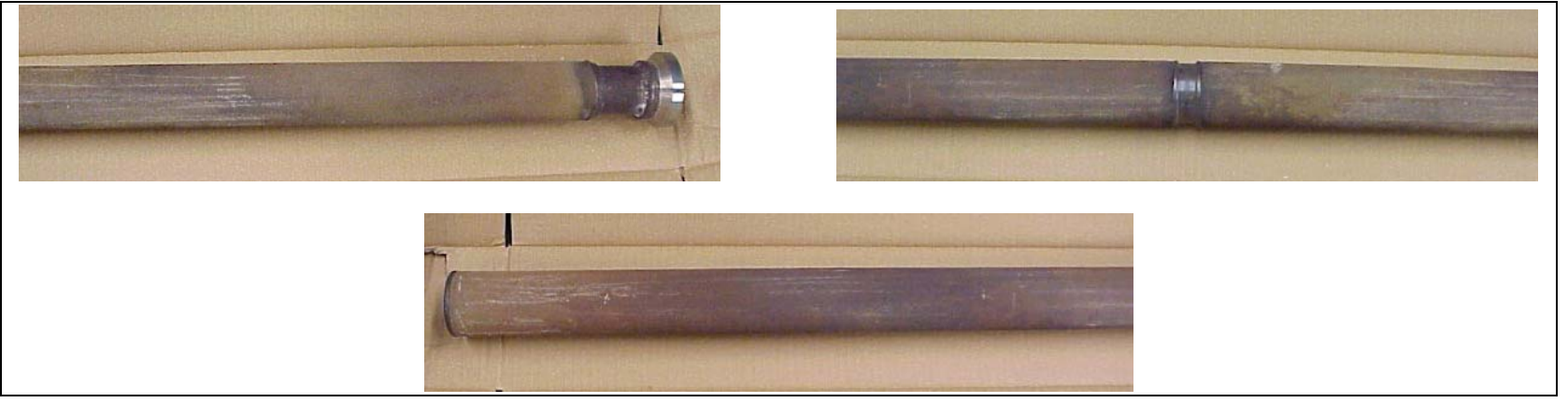

Figure 20: Pall M5 Filter with 316L Stainless Steel Filter and Media

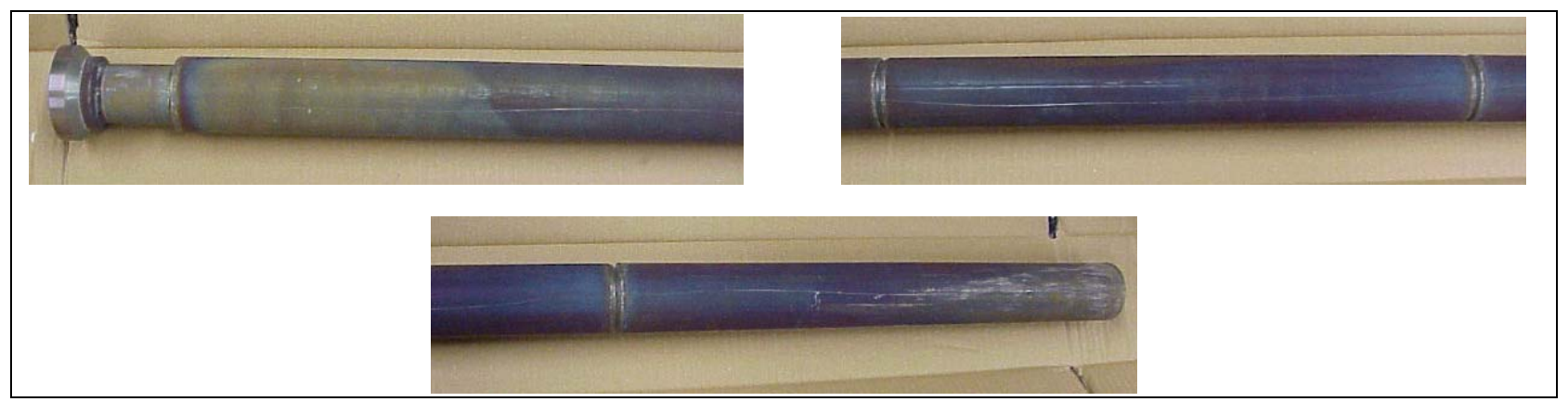

Figure 21: Pall P3 Filter with Inconel 600 hardware and Hastelloy Media 


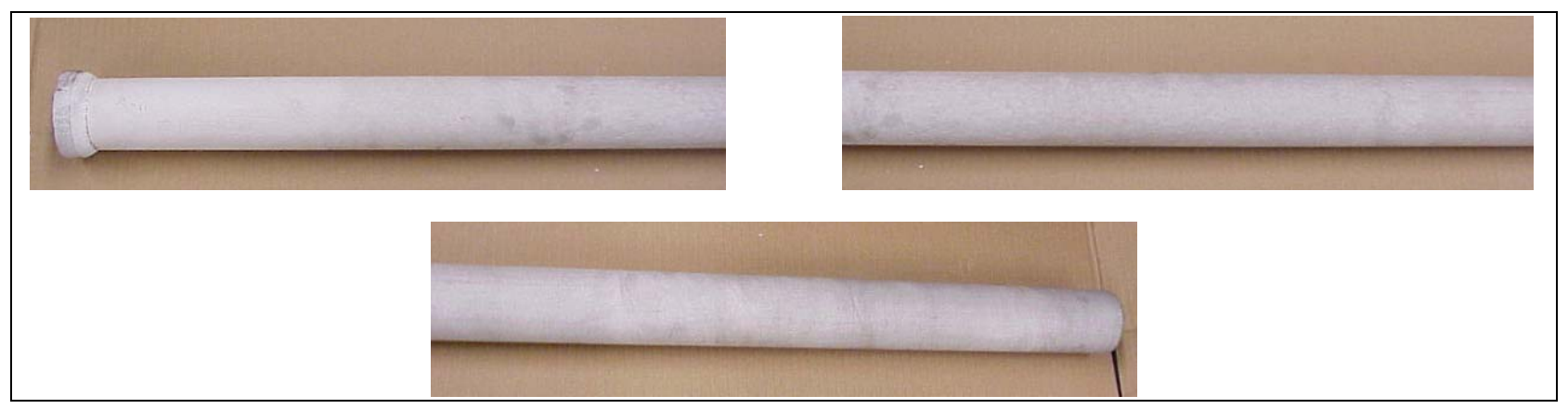

Figure 22: 465 Filter with SiC support and Alumina Media

The filters were visually examined. The Pall M5 filters had significant oxide growth on the filter surface attributed to corrosion of the 316L stainless steel. The P3 filter had corroded but to a significantly lesser extent The 465 filter exhibited essentially no change in the test period. Typically, the M5 filters are recommended for temperatures less than $420^{\circ} \mathrm{C}$, while the $\mathrm{P} 3$ filters are recommended materials for slightly higher temperatures. The 465 filters exhibit the widest range of corrosion resistance and are typically used for much higher temperature service or at critical temperatures of volatile halogens, i.e. near $600^{\circ} \mathrm{C}$. In this case, the $\mathrm{P} 3$ filter appears to be sufficient for the process. However, further analysis will be done with scanning electron microscopy (SEM) to determine the integrity of the fibers within the matrix.

\subsection{Process Baghouse Filter (PBF)}

The process baghouse filters process gas stream, once cooled in the off-gas cooler (OGC) and scrubbed for trace acid gases in the Quencher/Scrubber $(\mathrm{Q} / \mathrm{S})$ system, and reheated by the Reheater. The nominal temperature in this region is $150^{\circ} \mathrm{C} \pm 10^{\circ} \mathrm{C}$.

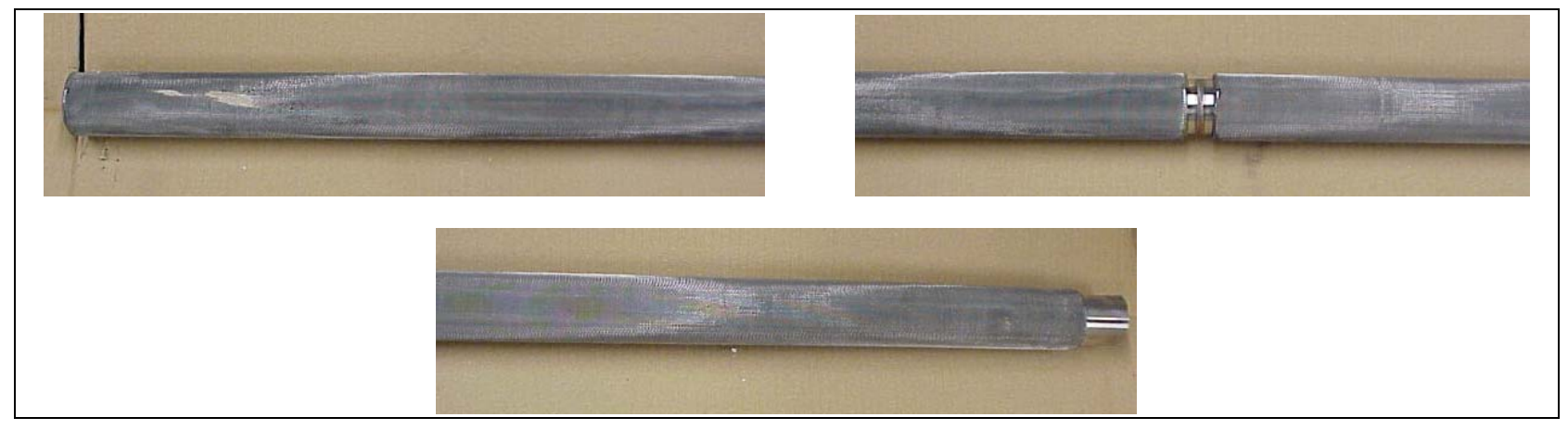

Figure 23: Porvair Stainless Steel Microfiltrex

The filter media did not appear to have any corrosion upon visual observation. The short exposure times may not have provided sufficient exposure to the corrosive gas stream. However, SEM can be done to determine the integrity of the mesh.

\section{CONCLUSIONS}

The analyses of the Hazen/TTT CP-2 Test Program corrosion coupons have been completed. The coupons in the CP-2 test program included wire samples that were exposed to the DMR freeboard, coupons exposed to the clean and the dirty (inlet) side of the Process Baghouse Filter (PBF), the PBF itself, and high temperature filters (HTFs). The following are the conclusions from the analyses:

- DMR Freeboard Wires: HR-160 alloy has performed the best on the surface, but the 53MD has the least void formation within the matrix. In contrast to the first test program, these wire coupons exhibited better corrosion performance, likely due to the lower temperatures and shorter exposures. 
- PBF Dirty Side: The nickel based alloys performed better than the superaustenitic stainless steel alloys, which in turn performed better than the traditional stainless steels. However, no significant variances were found within the nickel based alloys, most probably due to the short exposure times and relatively low temperatures.

- PBF Clean Side: No significant variances were found between the performance of each of the alloys, most probably due to the short exposure times and relatively low temperatures.

- High Temperature Filter: The P3 Hastelloy media filter appears sufficient, while the 465 alumina filter exhibited essentially no degradation.

- Process Baghouse Filter: The stainless steel mesh filter essentially underwent no degradation

The relatively low temperatures and short exposure times may not be sufficient to elucidate the subtle variances in the corrosion rates of the alloys exposed. However, these conclusions have been drawn based upon visual examination and microstructural evaluations. 


\section{REFERENCES}

[1] D. Dustin, "Pilot Plant Testing Plan for Treating Sodium-Bearing Waste Surrogates Using the THOR ${ }^{\mathrm{SM}}$ Steam Reforming Process, Rev. 1” Project Number: 28276, Document Number: 28276-21-0015-01, Washington Group International, Denver CO, October 2005.

[2] “Pocket Guide to Materials Performance in Industrial High Temperature Environments," Haynes International, Kokomo, IN, 2004.

[3] K. H. Subramanian, “Analyses of HAZEN Corrosion Coupons (U),” WSRC-TR-2006-00141, Washington Savannah River Company, April 2006. 